\title{
Improvement of educational literature of a new generation in distance learning as a second foreign language
}

\author{
Utkir SATTAROV 1 \\ Samarkand State Institute of Foreign Languages
}

\begin{tabular}{l} 
ARTICLE INFO \\
\hline Article history: \\
Received June 2021 \\
Received in revised form \\
20 June 2021 \\
Accepted 15 July 2021 \\
Available online \\
15 August 2021 \\
\hline Keywords: \\
German, \\
second foreign language, \\
material and technical base, \\
textbooks and teaching aids, \\
modern system of \\
pedagogical education, \\
didactic meaning, \\
Slatina, \\
information society, \\
integrated textbooks.
\end{tabular}

ABSTRACT

In recent years, in our country, much attention has been paid to improving the quality of education, improving the material and technical base of educational institutions, creating textbooks and teaching aids of a new generation, incorporating the latest achievements of modern science and technology and advanced world experience. This article is devoted to the improvement of a new generation of textbooks on distance learning of German as a second foreign language, methods of learning German and related literature, and their meaning.

2181-1415/@ 2021 in Science LLC.

This is an open access article under the Attribution 4.0 International (CC BY 4.0) license (https://creativecommons.org/licenses/by/4.0/deed.ru)

\section{Немис тилини иккинчи чет тили сифатида масофавий ўқитишда янги авлод ўкув адабиётларини такомиллаштириш}

\footnotetext{
Калит суизлар:

Немис тили,

иккинчи чет тили,

моддий-техник баъза, дарслик ва ўқув

қўлланмалар,

замонавий педагогик

таълим тизими,

дидактик маъно,

Слатина,

ахборот жамияти, интеграциялашган дарсликлар.
}

\begin{abstract}
АННОТАЦИЯ
Мамлакатимизда сўнгги йилларда таълим сифатини ошириш, таълим муассасаларини моддий-техник базасини такомиллаштириш, таълим жараёнида бугунги фан ва технологияларнинг сўнги ютуқларини ва бу борадаги жахоннинг илғор тажрибаларини ўзида мужассам этган дарслик ва ўқув қўлланмаларни янги авлодини яратишга катта эътибор қаратилмоқда. Ушбу мақолада немис тилини иккинчи чет тили сифатида масофавий ўқитишда янги авлод ўқув адабиётларини такомиллаштириш, немис тилини ўрганиш методлари ва унга мос адабиётлар, уларнинг ахамияти борасида тўхталиб ўтилган.
\end{abstract}

\footnotetext{
${ }^{1}$ Samarkand State Institute of Foreign Languages, Samarkand, Uzbekistan.
}

E-mail: uusattarovrgtf@gmail.ru. 


\section{Улучшение образовательной литературы нового поколения в дистанционном обучении как второй иностранный язык}

\author{
Ключевые слова: \\ немецкий язык, \\ второй иностранный \\ язык, \\ материально-техническая \\ база, \\ учебники и учебные \\ пособия, \\ современная система \\ педагогического \\ образования, \\ дидактический смысл, \\ Слатина, \\ информационное \\ общество, \\ интегрированные \\ учебники.
}

\section{АННОТАЦИЯ}

В последние годы в нашей стране большое внимание уделяется повышению качества образования, совершенствованию материально-технической базы учебных заведений, созданию учебников и учебных пособий нового поколения, вобравших в себя последние достижения современной науки и техники и передовой мировой опыт. Данная статья посвящена совершенствованию нового поколения учебников по дистанционному изучению немецкого языка как второго иностранного, методам изучения немецкого языка и соответствующей литературы, их значению.

\section{КИРИШ}

Мамлакатимизда сўнгги йилларда таълим сифатини ошириш, таълим муассасаларини моддий-техник баъзасини такомиллаштириш, таълим жараёнида бугунги фан ва технологияларнинг сўнги ютуқларини ва бу борадаги жахоннинг илғор тажрибаларини ўзида мужассам этган дарслик ва ўқув қўлланмаларни янги авлодини яратишга катта эътибор қаратилмоқда. Жамиятимиздаги бу каби ислохатларни Ўзбекистон Республикаси Президентининг “Олий таълим муассасаларида таълим сифатини ошириш ва уларнинг мамлакатда амалга оширилаётган кенг қамровли ислохотларда фаол иштирокини таъминлаш бўйича қўшимча чоратадбирлар тўғрисида" 2018 йил 5 июндаги ПҚ-3775-сон қарорида белгиланган вазифаларни бажариш, олий таълим муассасаларини илғор жахон тажрибалари асосида яратиладиган янги авлод дарслик, ўқув қўлланмалари хамда даврий нашрлар билан тизимли таъминлаш мақсадида Ўзбекистон Республикаси Вазирлар Махкамасининг 2018 йил 10 октябрьдаги “Олий таълим муассасаларини ўқув адабиётлари билан таъминлаш тўғрисида”ги 816-сонли қарорининг қабул қилиниши ва унда белгиланган вазифаларда хам кўришимиз мумкин.

\section{АДАБИЁТЛАР ТАХРИРИ}

Замонавий педагогик таълим тизимини ташкил этишга доир энг мухим масалалардан бири бу - юқори сифатли дарсликларни яратиш ва улардан фойдаланишдир. Замонавий, тез ўзгарувчан дунёда, керакли билимларни тақдим этиш ва тарқатиш шароитида дарсликларнинг ўрни хар қачонгидан хам долзарб бўлиб бормоқда. Дарслик - бу “ўқув жараёнида турли хил илмий ва касбий мазмундаги маълумотларни махсус форматланган дидактик восита ёрдамида фойдаланувчига етказадиган, ўқув жараёнининг мақсадларига, талабаларнинг психофизик етуклигини оширадиган, таълим ёки унинг босқичлари, яъни ўқув дастурлари, ишчи дастурлари талабларига мос келадиган муяйан бир китоб”. 
Оммавий таълим талабларига жавоб бўлиши билан дарсликлар асосий ўқув қўлланмасига айланди. Таълим сохасидаги барча ўзгаришлардан ва ислохотлардан қатъи назар, дарсликлар хали хам ўқитиш жараёнида мажбурий билим манбаи бўлиб қолмоқда. Дарсликларнинг алмаштириб бўлмайдиганлиги, юқори сифатли дарсларни ташкил этиш мумкин эмас деган хулосага келинади.

XXI аср таълимини белгилайдиган катта қарама-қаршилиирга тааллуқли бўлган замонавий ижтимоий таълим мунозаралари сўнгги дарсликларнинг ахамияти ва функцияларига янги муъёрларини кўрсатиб беради. Бу борадаги мунозараларнинг бири шундаки, бир томондан оммавий равишда "талабалар билимларини ошириш” бўлса, иккинчи томондан, билимларни сингдириш ва қайта ишлаш учун инсон қобилятига эътибор қаратилмқода. Бунга қўшимча равишда, замонавий дарсликлар ишлаб чиқаришнинг асосий парадигмаларидан бири бу ўқитувчиларнинг курс директорлари, ташкилотчилар, координаторлар, профессионал инструкторлар, репетиторлар каби янги функцияларини хисобга олиш хам талаб қилинади. Бундан ташқари бугунги кунда дунёнинг кўплаб мамлакатларида, хусусан Ўзбекистон таълим тизимида хам масофавий таълим ривожланиб, уни таълим жараёнида қўллаш жадал равишда такомиллашиб бормоқда. Бу жараёнда анъанавий ўқув адабиётларга қўйиладиган талаблар электрон дарсликларнинг хусусиятлари жихатидан фарқ қилади. Шу жихатлар хам методист олимлар томонидан янги авлод дарсликларини яратиш борасида қарамақарши фикрлилик холатлари учраб турибди.

Умуман олганда, дарсликлар “мажбурий матнли ўқитиш воситалари" сифатида, уларни ишлаб чиқариш ва замонавий курсни моделлаштириш учун фойдаланиш тамойиллари ва усуллари доимий равишда қайта бахоланиб турилиши шарти бўлган ўқув жараёнидаги асосий билим манбаларидан бири бўлиб қолмоқда.

Агар дарсликлар билан бошқа барча ўқув адабиётларни ажратиб кўрсатиладиган бўлса, шартли равишда, дарсларни педагогик-таълим жараёнининг бошқа компонентларидан ажратишнинг асосий таркибий қисмларига мурожаат қилиш керак. Булар қуйидагилар:

- ўқув дастурлари асосида тузилганлигига;

- аниқ мақсадга йўналтирилганлигига ва муддатининг чекланганлигига;

- ўқитувчи томонидан бошқарилишига ва назорат қилинишига.

\section{ТАДҚИҚОТЛАР МЕТОДИКАСИ}

Одатда дарслик тузиш учун асосий педагогик талаблар бир вақтнинг ўзида белгиланади ва қуйида улар батафсил тушунтирилади:

1. Педагогик ва дидактик дискурс нуқтаи назаридан, дарслик дизайни масаласи курс дастурлари масаласи билан боғлиқ тузилади, чунки дарсликлар, қоида тариқасида, ўқитишнинг алохида сохалари учун ўқув дастурига мувофиқ тузилади ва моделлаштирилади. Шунинг учун айтиш мумкинки, дарсликларнинг дизайни ва ишлаб чиқарилиши хар доим ўқув дастурларига асосланган. Дидактик маънода дарсликлар муайян курслар ва таълимининг маълум даражалари учун ўқув дастурларининг барча хусусиятларини экс эттириши керак. Ушбу хусусиятларга қуйидагилар киради: 
- уққув дастурида назарда тутилган курс мазмунини тақсимлаш тури (чизиқли, консентрик, спирал ва курс таркибини комбинациялашган холда);

- ўқув жараёнининг босқичлари бўйича дарс мазмунини тақсимлаш (ўқитиш сохаси, ўқитиш мавзуси, ўқув бўлими);

- дарс мазмуни хажми ва интенсивлиги (ўқув қўлланманинг ўқувчиларининг психофизик имкониятлари учун мўлжалланганлиги);

- бошқа курслар ва ўқитиш сохалари мазмуни билан боғлиқлиги (таълим сохалари, айрим турлари ва даражаларидаги барча дарсликлар ўртасидаги вертикал ва горизонтал боғлиқлик).

1. Дарсликлар ўқитиш жараёнида доимий билим манбаларидан бири эканлигини хисобга олиб, улар телеологик ўлчовни хам ўз ичига олиши керак, яъни улар тегишли курсда ўқитишнинг предмети, мақсад ва вазифаларига жавоб берадиган тарзда яратилиши керак. Мақсадлар шартли равишда учта гурухга бўлиниши мумкин: педагогик, ўқув ва функционал. Ўқитишнинг маълум бир сохаси ёки курсида талабаларга тегишли бўлган педагогик-ўқув-функционал шароит-ларда эришилиши керак бўлган барча нарсалар дарсликларда акс эттирилиши керак. Слатинанинг фикрига кўра, “Дарсликнинг илмий, мантиқий-методик, концептуалсемантик, дидактик-методик ва бошқа қийматларни ўз ичига олиши курснинг кўзланган мақсадлари билан боғлиқликда яратилиши лозим. Бироқ, белгиланган қийматларнинг ўзи хеч қачон ўқув жараёнининг аниқ мақсадлари ва вазифаларини амалга оширилишнинг кафолати бўлмайди". Тегишли дарсликни ишлаб чиқариш жараёни қуйидаги талабларга жавоб берадиган бўлса, мақсад ва натижаларга эришилади:

А) дарсликнинг тегишли дидактик форматланиши. Бу дарслик ишлаб чиқариш жараёнининг асосий талабидир, чунки дарсликнинг дидактик аппарати айнан мазкур дарсликни “талабанинг кундалик қизиқиши объекти”га айлантиради. Дарсликнинг дидактик дизайни қуйидагиларга асосланади:

- ўқитиш жараёнининг асосий тамойиллари (ўз-ўзини фаоллаштириш ва спонтанлик принципи, ўзаро таъсир ва алоқа принципи, долзарблик ва тўлиқлик принципи);

- дидактик қадриятлар ва принциплар (ёшга мослик принципи, тизимлаштириш ва босқичма-босқичлик принципи, далиллар принципи, рационалллик принципи, индивидуализм принципи);

- ривожланишнинг турли босқичларидаги ўқув жараёнлари (тахлил ва синтез, абстракция ва умумлаштириш, индуксия ва дедуксия, тизимлаштириш ва таснифлаш);

- курсларда ўқитиш ва ўрганишнинг қадриятлари ва тамойиллари (ўрганиш ва ўқитишнинг мажбурий уззаро боғлиқлиги, кузатиш, излаш ва кашф қилиш орқали ўрганиш, фаол ўрганиш тамойили);

- дарснинг босқичлари (кириш, амалга ошириш, билимларни тасдиқлаш, машқ қилиш, такрорлаш ва бахолаш).

Бундан ташқари, дарслик яратувчи бугунги замонавий ўқув жараёнидаги дарсликларга фақатгина ўқув таъминоти сифатида қарамаслиги ва шу билан бирга дарсликнинг дидактик форматлаши унинг бошқа барча ўқув воситалар билан дидактик-услубий жихатдан тўлдириш принципига амал қилишини ёдда тутиши керак. Слатинанинг фикрича, “фақатгина билимнинг турли хил манбалари ўртаси- 
даги бир-бирини тўлдирувчи боғлиқликда дарслик ўзининг хақиқий педагогиктаълим функцияларини бажариши мумкин. Шунинг учун дарсликнинг қиймати фақат унинг дарслик эканлигида эмас". Замонавий ахборот жамиятида талабани бошқа билим манбаларига йўналтириш ва уни ўқишга фаол ёндошишга ундайдиган дарсликларнинг айнан шу хусусияти, шу билан мавжуд барча билим манбаларини бирлаштириш, хар қандай дарсликда бўлиши керак бўлган асосий хусусиятдир. Шу нуқтаи назардан, ўқувчиларни таълим муассасаларида электрон таълимга, шунингдек масофавий ўқитишга тайёрлашга қаратилган дарслик-ларнинг алохида ахамиятини хам таъкидлаш керак.

Б) дарсликнинг тегишли график дизайни ва техник формати. Дарсликнинг график дизайни ва техник форматлаши шуни англатадики, дарсликнинг ташқи қиёфаси шу дарсга жалб қилинган талабаларда қизиқиш, изланувчанлик ва ғайрат уйғотиши, шунингдек, унинг фойдали бўлиши ва талабалар ёшига мос бўлиши керак. Тўғри иллюстрация ўқувчиларнинг дарсликни қабул қилиши ёки рад этишининг асосий омилларидан биридир. Иллюстрациялар дарсликнинг матн қисмларини қўшимча равишда бойитиши керак. Бу холат фақатгина бирон бир нарсани таъкидлаш учун ва қўшимча иллюстрация талаб этилган жойларда қўйилиши мумкин бўлади.

Сифатсиз ижодий-техник дизайн ва ёшга мос бўлмаган графикалар дарсликнинг тегишли эстетик талабларга жавоб бермаслигига олиб келиши мумкин. Шу билан бир қаторда, дарслик бошидан охиригача матнли бўлмаслиги керак, чунки талабалар ва айниқса, кичик ўқувчилар уни жозибали деб билишади. Дарсликда матннинг маъносига боғлиқ бўлган расмлар, чизмалар, графиклар, жадваллар бўлиши керак. Иллюстрациялар қора ва оқ ёки рангли бўлиши мумкин. Сарлавхалар ва кичик сарлавхалар бир текис тақсимланиши ва чиройли форматланиши керак. Қоғоз сифати дарслик талабларига жавоб бериши керак, муқовалари ўқувчиларни жалб қилиш учун дид билан ишланган бўлиши талаб этилади. Ва нихоят, дарслик катта бўлмаслиги керак, чунки бу ўқувчиларни зериктириб қўйиши мумкин. Дарсликнинг техник формати дарслик, трейнинг дарслик, тўплам деб номланишига боғлиқ. Интеграциялашган дарсликлар тегишли ўқув дастурида назарда тутилган барча таркибни ўз ичига олади, трейнинг дарсликлар турли хил машқлар китобларига тааллуқлидир, тўпламда бир нечта китоблар (ўқувчи, трейнинг китоблар, амалий ва х.к) ўқув дастурини ўз ичига олади.

\section{ТАДҚИҚОТ ВА НАТИЖАЛАР}

Ва нихоят, шуни таъкидлаш керакки, замонавий дарсликда унинг мазмунини бойитадиган дидактик-услубий, шунингдек, график-ижодий жихатидан турли хил қўшимча воситалар хам бўлиши керак. Бу, биринчи навбатда, асосий дарсликни миқдорий ва сифат жихатидан тўлдириш учун махсус ишлаб чиқилган CD ва DVD каби ёрдамчиларга тегишли (дарслик дизайни учун мултимедиа ёндашуви) бўлади. Дарсликдан фойдаланиш шу каби барча қўшимча воситалардан фаол (ижодий) фойдаланишни хам талаб қилади.

В) дарсликнинг тегишли лингвистик форматланиши. Дарсликлар билимларни тарқатиш учун мухим воситалардан биридир. Шу сабабли, ўқув қўлланмаларининг лингвистик формати энг нозик масалалардан бири бўлиб, муайян талабалик ёшига лингвистик жихатдан мослиги ва матнли ва расмли қисмларнинг таркиби энг мухим ва энг мураккаб жихатлари хисобланади. “Дарсликда 
ишлатиладиган тилни танлаш аста-секин унинг информацион ахамиятлилигининг энг мухим мезонига айланиб бормоқда, чунки тил маълумот узатишда хизмат қилади, тил фойдаланувчига мулоқот воситаси хисобланади ва агар бу "мулоқот жамияти” ва унинг фойдаланувчиси мулоқотда хатоликка дуч келган бўлса, мулоқот самарали бўлмайди ва дарсликнинг билим манбаи сифатида мақсади бахсли бўлиб қолади!”. Демак, дарслик тузиш жараёнида тилшунос мутахассисларнинг ижодий иштироки нафақат дарслик матнни тузатиш нуқтаи назаридан, балки дарслик матнини танлашда (ўқувчиларнинг ёшига қараб, ўқув дастуридан келиб чиққан холда) муаллифлар билан биргаликда харакат қилиш керак. Бу жуда мухимдир, чунки талабалар уззарининг дарсликларида ишлатилган маълумотлар асосида ихтисослаштирилган илмий ва бадиий регистрларнинг сўзларини ўрганади. Шунинг учун дарсликларнинг тўғри лингвистик форматлаши илмий принциплар ва ўқув жараёнида ўқувчилар ёшига мослиги ўртасида махсус боғлиқликни таъминлайди.

Г) дарсликнинг тегишли гигиеник форматлаш.

Дарсликлар ўқувчиларнинг кундалик ва доимий алоқада бўлишлари учун ўқув воситаси хисобланади, шунинг учун дарслик тайёрлаш жараёнида ўқувчиларнинг соғлиғига эътибор қаратиш керак. Вилотижевич, бу, айниқса, ўқувчиларнинг кўриш қобилиятига тааллуқли деган фикрни илгари суради ва қуйидагиларни таъкидлайди: Матн ёзувлари ўқувчилар томонидан 20 см оралиғида аниқ кўриши учун етарлича катта бўлиши керак. Чизиқлар орасидаги масофа тенг ва асосли бўлиши керак. Сарлавхалар ва кичик сарлавхалар визуал равишда маълум бир мавзу ва унинг қисмларини акс эттириши керак”. Бундан ташқари, дарсликдан фойдаланадиган ўқувчилар соғлиғига зарар етказмаслик учун дарслик материаллари ва босиб чиқариш учун ишлатиладиган бўёқ турларини хам хисобга олиш керак. Хатто жуда ёш талабалар хам хар куни кўпайиб бораётган дарсликлар ва қўлланмалардан фойдаланишга ва олиб юришига мажбур бўлишларини хисобга олсак, дарсликнинг хажми ва вазнига хам эътибор қаратиш лозим.

3. Замонавий дарслик яратиш жараёнида юқоридаги мезонларга жавоб бериш ўз-ўзидан дарсликнинг барча функцияларини бажаришига олиб келмайди. Синфлар учун дарсликлардан фойдаланиш “ўқитувчининг ижодий саъй-харакатлари билан чамбарчас боғлиқ”. Ўқитувчиларнинг ижодий саъй-харакатлари ўқувчиларга замонавий мултимедиа мухитида уларни бошқа манбалар билан интеграллашган холда ўрганиш учун ўқув қўлланмаларидан қандай қилиб яхшироқ фойдаланишни кўрсатиб бериши керак.

Ўқитувчилар дарсларнинг яратувчиси ва етакчиси сифатида бирон бир асосий функцияларни дарсликларда катта эътибор қаратмаслиги лозим, яъни ўқитувчилар таълим жараёнининг барча босқичларини хисобга олишлари керак. Дарслик ўқув жараёнида белгиланган натижалар ва мақсадларни хисобга олган холда барча босқичлардан узвий равишда ишлатилиши керак. 


\section{ХУЛОСА}

Хулоса ўрнида шуни айтишимиз мумкинки, дарсликлар хар доим хам асосий ўқув воситаларидан бири бўлиб келган ва шундай бўлиб қолаверади, шу сабабли уларни лойихалаш жараёнига алохида эътибор бериб келинган. Бугунги кунда бу жараён хар қачонгидан хам мухимроқ. Замонавий дарсликларни ишлаб чиқариш ва улардан фойдаланиш учун асосий педагогик мезон ва белгиловчи омиллар доимий равишда қайта бахолашни ва такомиллашувни талаб қилади. Дарсликларни ишлаб чиқариш ва улардан фойдаланишнинг педагогик детерминантлари синфларнинг моқиятига ва уларнинг педагогик-таълим жараёнининг барча жихатларини қамраб олинишига асосланади. Демак, дарсликларни ишлаб чиқариш хар доим таълим муассасаларининг муайян турлари ва даражалари учун ўқув дастурлари, дарсларнинг мақсади ва натижалари билан бевосита боғлиқ бўлиб, дарслик яратиш жараёнида тегишли дидактик, график дизайн, лингвистик, гигиеник форматлаш; шунингдек, дарсликларни ўқитиш методларини танлашда ва дарсларни ташкил этишга алоқида эътибор қаратиш лозим. Дарсликларни яратиш ва дарсликка қўйиладиган мезонларни аниқлаш хар доим ва хар бир таълим тизими учун мухим ахамиятга эга бўлади. Таълим ва таълимни такомиллаштириш бўйича хар қандай харакат ўқув жараёнининг барча босқичларида дарсликларни такомиллаштиришни ўз ичига олиши керак.

\section{ФОЙДАЛАНИЛГАН АДАБИЁТЛАР РЎЙХАТИ:}

1. Potkonjak, N., Šimleša, P. (ur.), (1989), Pedagoška enciklopedija 2, Beograd, Zagreb, Sarajevo, Titograd, Novi Sad: Zavod za udžbenike i nastavna sredstva.

2. Stevanović, M. (1998), Didaktika, Tuzla: R\&S.

3. Slatina, M. (2005), Odindividue do ličnosti-uvođenje u teoriju konfluentnogo obrazovanja, Zenica: Dom štampe. - P.137.

4. Slatina, M. (1998), Nastavnimetod, Sarajevo: Filozofskifakultet.

5. Vilotijević, M. (2001) Didaktika3, Sarajevo: BH most.

6. Potkonjak, N., Šimleša, P. (ur.), (1989), Pedagoška enciklopedija 2, Beograd, Zagreb, Sarajevo, Titograd, Novi Sad: Zavod za udžbenike i nastavna sredstva. - P.473.

7. Беспалько В.П. Теория учебника: Дидактический аспект. - М.: Педагогика, 1988. - С. 160.

8. Беспалько В.П. Теория учебника. - М.: Педагогика, 1988, - С. 160.

9. Агеев В.Н. Электронные издания учебного назначения: концепции, создание, использование / В.Н. Агеев, Ю.Г. Древе. - М.: 2003, - С. 236.

10. Зайнутдинова Л.Х. Создание и применение электронных учебников (на примере общетехнических дисциплин). - Астрахань: Изд-во ЦНЭП. 1999, - С. 364.

11. Wulf W.A. 2003. "Higher Education Alert: The Information Railroad is Coming". Educause, Jan./Feb.

12. Вымятнин В.М., Демкин В.П., Можаева Г.В., Руденко Т.В. Мультимедиакурсы: методология и технология разработки, Томск 2003// http://ido.tsu.ru /ss/?unit=223.

13. Casey J. (1994) Integrating Computers in the Primary Classroom. The Computing Teacher, 21. - PP. 33-36. 